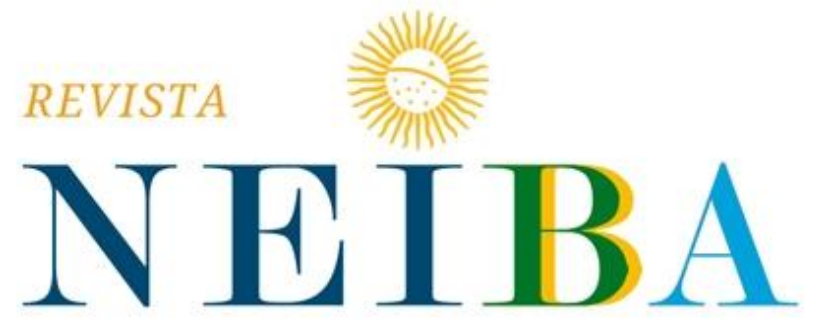

CADERNOS ARGENTINA-BRASIL
Volume 9,2020 , p. 01-21

DOI: 10.12957/neiba.2020.51159 I e51159 I ISSN: 2317-3459

\title{
ACHIEVING SUSTAINABLE AND INCLUSIVE ECONOMIC GROWTH IN LATIN AMERICA: NATIONAL DEVELOPMENT DURING THE COMMODITY BOOM
}

ALCANÇANDO CRESCIMENTO ECONÔMICO SUSTENTÁVEL E INCLUSIVO NA AMÉRICA LATINA: DESENVOLVIMENTO NACIONAL DURANTE O BOOM DAS COMMODITIES

\section{David R. Mares ${ }^{1}$}

${ }^{1}$ University of California, San Diego, California, Estados Unidos. E-mail: dmares@ucsd.edu ORCID: https://orcid.org/0000-0001-6299-0829

Recebido em: 01/01/2020 | Aceito em: 27/04/2020. 


\section{ABSTRACT}

This article examines how government policy affects the sustainability and inclusiveness of national development after the boom. The impact of the latest commodity boom (2003-2014) on the sustainability and inclusiveness of Latin American national development varies, but not by whether governments were ideologically left. I present the economic results of the commodity boom for the major Latin American countries, followed by the social results as measured by the reduction in poverty rates and income inequality. I examine potential countervailing economic factors that could mitigate the importance of the political economic determinants of the use of resource wealth. Finding the countervailing economic factors inadequate to explain the variation in social results, I propose that the political economy of linking resource wealth with economic and social outcomes is the key determinant. I conclude the paper with a discussion of current challenges post-commodity boom.

Keywords: Commodity Boom; Poverty; Income Inequality.

\section{RESUMO}

Este artigo examina como a política do governo afeta a sustentabilidade e a inclusão do desenvolvimento nacional após o boom. O impacto do último boom das commodities (2003-2014) na sustentabilidade e inclusão do desenvolvimento nacional da América Latina varia, mas não pelo fato de os governos serem ideologicamente de esquerda. Apresento os resultados econômicos do boom das commodities para os principais países da América Latina, seguidos pelos resultados sociais medidos pela redução das taxas de pobreza e desigualdade de renda. Examino os possíveis fatores econômicos compensatórios que podem mitigar a importância dos determinantes políticoeconômicos do uso de recursos financeiros. Considerando os fatores econômicos compensadores inadequados para explicar a variação nos resultados sociais, proponho que a economia política de vincular os recursos financeiros a resultados econômicos e sociais seja o principal determinante. Concluo o artigo com uma discussão dos desafios atuais do pós-boom das commodities.

Palavras-chaves: Boom de Commodities; Pobreza; Desigualdade De Renda. 


\section{ECONOMIC RESULTS OF THE COMMODITY BOOM}

Latin America is comprised of commodity exporting countries with distinct economic structures. Mexico, an important oil exporter during the boom, has the most diversified economy. The North American Free Trade Agreement (NAFTA), created an important manufacturing sector exporting to the United States, whose value roughly equaled that of oil exports during the commodity boom. Proximity to the U.S. also generates significant foreign exchange via remittances from migrants working there and tourism. Consequently, oil exports accounted for only $25-30 \%$ of foreign exchange earnings. Contrast Mexico with Venezuela, where some $90 \%$ of foreign exchange is earned by oil exports. The importance of commodity exports for the other major Latin American countries lies in between these two extremes.

Table 1 provides the composition of commodity exports for Latin American countries except Mexico at the height of the commodity boom, 2010-2012. Venezuela and Chile stand out for dependence on one commodity, oil and copper, respectively. But Colombia and Ecuador had more than $90 \%$ of their commodity exports represented by just three products (crude oil/coal/coffee and crude oil/bananas/shrimp, respectively) while for Bolivia the top three were almost $80 \%$ (natural gas/zinc/soybean meal).

The commodity boom was greatest for oil, with prices increasing almost fourfold between 2003 and 2013, followed by the tripling of metal prices, a doubling of food prices and an increase of 50 percent for agricultural products in the same period. dramatically increased GDP growth in the region, with average annual growth rates of less than 2.5 percent in the period 1980-2002 accelerating to above 4 percent in 20032011. Growth rates slowed significantly when prices leveled off at the end of the commodity cycle, but growth was still are relatively high rates, 3.1 percent in 2012 and 2.7 percent in $2013 .^{2}$

Economic growth in Latin America fell each year from 2012-2016, becoming a recession in 2015 , despite commodity price levels that were still high by historical standards until 2014. And it was only after 2016 that Latin American economies were

\footnotetext{
${ }^{2}$ Gruss, "After the Boom"
} 
buffeted by non-commodity related factors arising from global economic and political risks. According to the World Bank, South America was the only region in the world to experience a significant economic contraction from 2012-2015. A slowing of Chinese growth was not the chief culprit; countries in Asia which have closer ties to China than South American countries, still managed to retain economic growth rates at 4-5 percent in this period. Since South American economies are far more dependent on commodity exports than Mexico, Central America and the Caribbean the brunt of the impact has been in South America. ${ }^{3}$

The benefits for a number of Latin American economies during the commodity boom were partially influenced by the lessons learned in dealing with the economic crises of the 1980s and 1990s. Inflation was now understood to be a real threat to the economy and society (except in Argentina and Venezuela). Inflation rates were quite restrained, falling from a Latin American norm of 25-30 percent for decades to 3-6 percent during the boom. International reserves were accumulated, and governments sold off many unproductive state-owned enterprises (SOE) across the economy, though again Venezuela was the big exception where SOE's expanded as the private sector disinvested in the face of political and economic turmoil.

Of course, it has been argued that resource wealth contains the seeds of economic destruction via either the "Dutch Disease" or the "Resource Curse". The "Dutch Disease" refers to the overvaluation of a currency that results from a commodity boom producing significant inflows of foreign exchange. The strong currency makes imports cheaper, thus disadvantaging any competing local production and resulting in reduced employment and entrepreneurship in those sectors or products. The strong currency also makes non-dollar denominated exports more expensive, thus weakening noncommodity exports with a resultant loss of wealth and employment. Investment patterns in the local economy are also diverted away from import-competing product lines and non-commodity export production, to the detriment of the economy when the commodity boom weakens. According to the World Bank, the negative impact on

\footnotetext{
${ }^{3}$ The World Bank, The Commodity Cycle in Latin America: Mirages and Dilemmas SEMIANNUAL REPORT Office of the Regional Chief Economist, April 2016, pp. 11-13.
} 
non-commodity tradable production was greatest in countries where domestic demand grew fastest, and currency overvaluation was greatest. ${ }^{4}$

There are, nevertheless, mitigating factors for Dutch disease dynamics. Some of that foreign exchanged can be used to purchase foreign assets or saved abroad. Brazil used some funds for an early payoff of an IMF loan from 1990s, thereby paying down its foreign debt. Stabilization funds can be created both to sterilize a portion of the revenue and save for leaner times; the fact that Venezuela burned through its stabilization fund shortly after creating it demonstrates the need for self-restraint. A country can also invest in productivity-enhancing endeavors (infrastructure, human capital, technology - not just elementary level education, make-work projects or noncompetitive industries) to increase the efficiency and competitiveness of the national economy in the medium and longer term.

The 'Resource Curse' develops when an inflow of vast wealth to the government reduces fiscal and institutional constraints on leaders. In particular, there is a weakening of the institutions designed to create transparency of government action and accountability of government leaders. Unleashed from such constraints the government spends on ostensibly important projects such as public housing and education, but in a manner that is wasteful and unsustainable. This pattern of expenditures results in a waste of the wealth while society and government grow dependent on the continued generation of that wealth. Examples include the transfer of wealth to cronies and patronage to constituents, an increase in public and private corruption, and societal demands for short-term transfers.

There are solutions to the 'Resource Curse' but they have political costs for government officials and economic costs for segments of society. Studies demonstrate that the antidote is ensuring transparency and accountability in how the funds are captured by the government and used by the public and private sectors. But doing so means that politicians forego opportunities for individual and constituent rent-seeking, thus reducing their chance to gain wealth and reelection. Requiring efficient and effective provision of goods and services to sectors of society in great need also means

\footnotetext{
${ }^{4}$ The World Bank, The Commodity Cycle, p. 23
} 
taking longer to address those needs, even if it means that such provision will be sustainable for a longer time. Since sustainability does not carry as much political weight as speed when there has been a lack of trust, this cost links back to politicians' interests in being reelected.

\section{SOCIAL RESULTS OF THE COMMODITY BOOM}

There are many dimensions to social welfare and ultimately the long run improvement to social welfare is the aspect of economic growth that matters most for a nation's development. The commodity boom of 2003-2014, however, is too recent to analyze the various components of social welfare and their long run impacts on the region's development. In this paper, therefore, I examine two factors that contribute to that long run improvement: poverty rates and the distribution of income in a country as indicated by the Gini index. While there are other measures that have been used to evaluate social welfare, such as the Human Development Index of the United Nations Development Program $\left(\right.$ UNDP $\left.^{5}\right)$, the lack of continuity in yearly data pre-commodity boom, commodity boom, and post-commodity boom, make comparative analysis difficult.

This paper's analysis provides some indication of the impact of the commodity boom on poverty rates and income concentration by comparing the pre-boom years of 2000-2002 with 2003-2014. Prices for every significant commodity the region exports were high during the boom and governments of both the left and right invested in social and economic infrastructure. The question of the sustainability of the impact is considered by adding in a comparison regarding poverty and income concentration for the years 2015-2017.

\subsection{Poverty}

Poverty rates, as measured by the percent of the population living in households with income per person below the national poverty line, were significantly higher in 2000-2002 than in the commodity boom era (2003-2014) across the region. Table 2 provides data on the nine major commodity exporters in Latin America: Argentina,

\footnotetext{
${ }^{5}$ United Nations Development Programme, Human Development Report, http://hdr.undp.org/en/humandev
} 
Bolivia, Brazil, Chile, Colombia, Ecuador, Mexico, Peru and Venezuela. The data indicates that prior to the start of the commodity boom poverty rates in all these Latin American countries except Argentina and Venezuela were higher than during the boom. The Argentine exception reflects the sudden and dramatic collapse of the economic in 2001; thus the improvement in the poverty rate in 2003 and 2004 only brought the country back to the level in 2000. Regarding Venezuela, the national strikes during efforts to overthrow the government in 2002 and 2003 also created an artificially high poverty rate.

Although the World Bank systematically collects and standardizes economic data for comparison, there are significant gaps in two important cases when we turn to evaluating whether some countries did better than others in reducing poverty. Venezuela has not provided data since 2006. Although one might hypothesize that the famous Missiones social welfare programs of the Bolivarian Revolution would have produced a significant decline in poverty, the data leaves room for skepticism. These programs began in 2004 but the poverty statistics hardly moved in 2004 and 2005, and in 2006 they were roughly back to where they had been in 2001. As mentioned, the government ceased reporting poverty rates after 2006 and we know that inflation was high in Venezuela even before the collapse of oil prices in 2014 and the subsequent crash into hyperinflation. Argentine national accounts are tainted by its significant understating of inflation rates between roughly 2010-2016, ${ }^{6}$ but as Table 2 demonstrates poverty fell significantly before these reporting problems.

One of the favorite explanations for declining poverty rates in Latin America points to the existence of Pink Tide governments (left-oriented governments) rather than to the commodity boom because these governments ostensibly favored state over market regulation of the economy. The data in Table 2 , however, indicates that progress on poverty reduction during the commodity boom was higher where public policy favored market control over the economy. Brazil is the stellar performer, with a decline in poverty rates of some 80 percent from 2003-2014. But though these were the years of the Pink Tide government of Luiz Inácio Lula de Silva, he, unlike the other Pink Tide

\footnotetext{
${ }^{6}$ The Economist, "Argentina's new, honest inflation statistics", May 25, 2017: Public Radio International, "Argentina likely manipulating Big Mac prices to keep inflation seemingly lower", February 7, 2012
} 
governments of Argentina, Bolivia, Ecuador and Venezuela, was pro-market in his economic policies.

Other pro-market countries did well. Peru and Chile experienced a more than 70 percent decline in poverty rates from 2003-2014 and 2003-2013, respectively (no Chilean data for 2014). Though Chile had Pink Tide governments 2000-2010 they were significantly constrained by the Chilean Constitution and the Legislature; the most significant declines in poverty occurred during Conservative government 2010-2014. Colombia's poverty rate fell by more than 50 percent from 2003-2014. Pro-market Mexico, with the most diversified economy of the large commodity exporters, already had the lowest poverty rate among these countries in 2000 yet still cut it by more than $50 \%$ to remain the best performing country on this metric in 2014 (given the lack of credibility of Argentine rates noted above).

We turn now to the countries favoring state control, again excepting Venezuela for which we have little data. Argentina's poverty rate more than doubled with the economic collapse of 2001-2002, and then decreased some 50 percent between 2005 and 2009 with the introduction of state controls over the economy; as noted, inflation distortions in the data from at least 2010 to 2016 make further decreases difficult to estimate. Bolivian poverty rates began an erratic decline under pro-market governments at the beginning of the commodity boom. With the statist government of Evo Morales rates fell significantly in 2006, with the decline slowing from 2007-2009 and no data reported in 2010. For 2011 a 30\% drop was recorded over 2009 and then an erratic decline of approximately $20 \%$ to 2014 . Ecuador experienced a phenomenal decline in poverty rates from 2000 to 2006 under pro-market governments (from 28 to 8 percent), and under the pro-state control government of Rafael Correa the decline first rose slightly in 2007, then declined slowly, picking up speed in 2013-2014.

As noted, the sustainability question can only be answered tentatively given the recentness of the end of the commodity boom. The data from Argentina for the period 2015-2017 is not credible given the aforementioned manipulation with inflation statistics. From Table 2 we can see that in this post-boom period poverty increased in two countries: Brazil and Ecuador; though Venezuela has not reported data since 2006, 
it is clear that whatever its levels were between 2007-2014, poverty levels in Venezuela have increased dramatically 2015-2017. In Bolivia, poverty levels increased in 2015 and 2016, then dropped back to the level of 2014, while in Chile poverty levels increased initially, then fell back down to new levels. These countries were all led by Pink Tide governments; though Dilma Rousseff in Brazil was impeached in August 2016 poverty rates already began increasing in 2015. Poverty levels in the three non-Pink Tide governments (Colombia, Mexico, and Peru) were able to sustain the reduction in poverty levels even after the commodity boom.

\subsection{Gini Index - Inequality}

Table 3 indicates that the performance of these Latin American countries on reducing the concentration of income was erratic before the commodity boom began in 2003. The Gini index worsened in Argentina, Peru and Venezuela, remained stable in Brazil and improved in Bolivia, Colombia and Mexico; Chile and Ecuador do not provide more than one year of data. During the boom years, each of these countries decreased inequality, though at different speeds and with the cautionary note about Argentine statistics and the lack of data for Venezuela. The sustainability of that improvement after the commodity boom (2015-2017) is more problematic. In Venezuela (we know despite the lack of data) and Brazil inequality worsened, while in Mexico and Peru the improvement experienced during the boom stagnated. No data is reported for Argentina during these post-boom years, and only four countries were able to continue to improve their Gini indices: Bolivia, Chile, Colombia and Ecuador.

\section{POTENTIAL COUNTERVAILING FACTORS}

After the commodity boom there could be various elements that could take up some of the slack, including domestic savings, foreign direct investment, and Chinese official loans. I exclude international capital flows into financial markets because of their inherent instability and contribution to capital flight that can rapidly undermine a domestic economy (such as occurred in Argentina from 1999-2001). 


\subsection{Domestic Savings}

Increase in domestic savings dampens inflation by both reducing consumption (thus decreasing demand) and increasing the capacity of the financial sector to fund productive investments (thus increasing supply). Latin America has historically had a comparatively low savings rate and the contemporary period is no exception. One study calculated that compared to the emerging Asian countries, Latin American gross public savings are almost two-thirds lower. For the years analyzed, 20017-2014 and comprising most of the commodity boom, Latin American governments spent 90 percent of their increased spending on current consumption. The picture is almost as bad for private savings, with Latin American private savings below 60 percent of the emerging Asian economies and just under 70 percent of their counterpart in the advanced economies. ${ }^{7}$ Unless there is a dramatic change in public and private spending, therefore, domestic savings cannot compensate for the decline in commodity prices.

\subsection{Foreign Direct Investment, FDI}

Inflows of FDI to Latin America have fallen for three consecutive years, 2015-2017 ${ }^{8}$, the same years that constitute our post-commodity boom sample. The decline in flows is fundamentally associated with the end of the commodity boom since the extractive industries were a key sector attracting FDI. In addition, slowing growth and recession in the wake of the commodity boom made these economies less profitable and thus less attractive places for non-extractive foreign direct investment.

But there are more structural and global factors at play that limit the region's attraction for FDI. The increasingly high technological requirements in global value chains are shifting investment patterns to the developed countries and China, leaving developing areas with the lower value-added manufacturing phases. An increase in geopolitical tensions is also disrupting and threatening global trade patterns, leading firms to consider placing more manufacturing processes within the developed countries and China rather than in the developing economies. ${ }^{9}$

\footnotetext{
7 Matthew M. Taylor. "Latin America's Savings Problem" Council on Foreign Relations July 14, 2016 https://www.cfr.org/blog/latin-americas-savings-problem June 4, 2019

${ }^{8}$ Economic Commission for Latin America and the Caribbean (ECLAC), Foreign Direct Investment in Latin America and the Caribbean, 2018 (LC/PUB.2018/13-P), Santiago, 2018.p. 29

${ }^{9}$ ECLAC, Foreign Direct Investment, ECLAC keynotes for development ISSN 2522-7459 Nº 1 October 2017
} 
There are bright spots for FDI, including renewable energy. But these are minor sources of capital and government revenue in the overall picture and thus do not compensate much for the decline in commodity prices.

Many Latin American analysts expect that China's expanding economy (even given its current slowdown) will produce continued interest in Latin American commodities, infrastructure needs and markets. They expect, therefore, Chinese FDI to facilitate economic adjustment until the next commodity boom. The data, however, suggests that China does not currently play this role and has little interest in adopting that role.

In 2016 FDI to Latin America originated most importantly from the European Union (53 percent). In fact, the EU accounted for more of the new investment in Latin America and the Caribbean for the period 2005-2017 with 39 percent; North America (Canada and the U.S.) followed with 32 percent. New investment from China (including Hong Kong SAR) was far behind at 5 percent of the total, even below the 9 percent that was generated by Latin American investors themselves. ${ }^{10}$ Chinese FDI from 2003-2016 concentrated on two countries, Brazil for $\$ 61$ billion and Peru for $\$ 18$ billion; no other country received more than $\$ 6$ billion. ${ }^{11}$

The destination of Chinese FDI in 2013-2016 compared to 2003-2012 increased in the service sector (mainly transport, finance, electricity, information and communications technology) from 20 percent to roughly 39 percent, and in alternative energy from about 1 percent to 10 percent. The big loser was the extractive sector, followed by manufacturing and agriculture. ${ }^{12}$ But after the Chinese government decided to guide FDI to fit into their One, Belt, One Road program and their industrialization strategy "Made in China 2025", Chinese investment in Latin America reverted to its earlier focus on energy and transport. ${ }^{13}$

\subsection{Chinese lending}

There is much discussion in the region regarding the potential of China's interest in competing with the U.S. for influence in the region to facilitate the region's adjustment

\footnotetext{
${ }^{10}$ ECLAC, Foreign Direct Investment, p. 169

11 Rolando Avendano, Angel Melguizo, and Sean Miner. Chinese FDI in Latin America: New Trends with Global Implications Washington DC: Atlantic Council, 2017. p. 7

${ }^{12}$ Avendano, Melguizo, and Miner. Chinese FDI in Latin America, p. 6

${ }^{13}$ ECLAC, Foreign Direct Investment
} 
to negative market forces. Since Chinese FDI responds to productive interests and we have seen that Latin American contributions here are largely confined to commodity exports, pro-China advocates in the region turn to geopolitics. The argument here is that the Chinese government will use government loans to keep Latin American governments from experiencing economic declines of a magnitude that would force them to turn to the U.S. and the multilateral institutions of the Liberal Economic Order.

Chinese lending from official sources Chinese Development Bank (CDB) and ExportImport Bank (Eximbank,) was a significant source of funding for some Latin American countries through the commodity boom. Tracking the actual disbursement of loans is difficult, but there is data regarding the announcement of Chinese loans to Latin America. From this data we can see that initially, China stepped up in 2015 after the commodity boom with loans rising from US\$13 billion in 2014 to US\$21.5 billion. Of that total, however, over $90 \%$ went to only three countries: Brazil $\$ 7.5$ billion, Ecuador $\$ 7$ billion and \$5 billion for Venezuela. Chinese loans fell off dramatically in 2016 (\$10.3b) and 2017 (\$6.2b), reaching their lowest levels since 2009. In 2017 Brazil alone received $\$ 5.3 b$ of the reported $\$ 6.2 b$, an even greater concentration of Chinese loans than previously. ${ }^{14}$ With Chinese loans decreasing in total and concentrated on specific countries the region cannot consider China as a source of funding to counteract the decline in commodity prices.

\section{THE POLITICAL ECONOMY OF LINKING WEALTH AND DEVELOPMENT}

All these countries were hit by the commodity boom - all had unexpected wealth generated, high levels of GDP growth and all had dramatic decline in the commodity export earnings. BUT what they did with that wealth determined how their economy was structured and how sustainable the social improvement will be now that the commodity boom has ended. The political economy of the budget is the underlying issue. In this section I present three fundamental political factors usually ignored by analysts seeking to explain variations in economic performance across Latin America.

\footnotetext{
${ }^{14}$ Calculated from Gallagher, Kevin P. and Margaret Myers (2019) "China-Latin America Finance Database," Washington: Inter-American Dialogue
} 
Most Latin American countries (Venezuela and Argentina were the exception) learned the importance of maintaining fiscal balances from the economic meltdowns of the 1980s and 1990s. Thus, they entered they entered the downturn after the commodity boom with low inflation and at least a modicum of foreign exchange reserves. Slower growth was not avoided, but the creation of a severe run on the national currency and balance of payments crisis was dodged except in Venezuela and Argentina. Yet we have noted that post-commodity boom performance on social welfare does not break down into a binary division of Venezuela/Argentina compared to the other seven economies in this study. Hence, economic factors alone cannot account for the differences.

Many advocates as well as critics of government policies over commodity exports make ambiguous and contradictory references to 'resource nationalism' in the defense of their arguments. Though the concept is generally used in the case of subsoil resources, many critics of foreign ownership of agricultural land and water distribution systems, or exports of food crops worry that national needs will be subordinated to foreign interests and call for government prohibition or significant regulation in the name of national security. These claims, therefore, are also being made in the name of nationalism about 'strategic' resources within the nation.

Unfortunately, there is no accepted definition of the concept 'resource nationalism'. If the concept of 'resource nationalism' is to be analytically useful we a clear and non-tautological definition. I propose that Resource Nationalism (RN) is most usefully defined as a perspective about public policy regarding national resources that is based on four interrelated claims: 1) the natural resources, whether publicly or privately owned, constitute a 'national patrimony"; 2) the proper usage of wealth generated from national resources is for the provision of public goods; 3) the government determines how the wealth generated from natural resource is used; and 4) sometimes the government uses the wealth for the generation of public goods and sometimes it does not. RN thus provides legitimacy for government to intervene in the market, but RN does not determine whether that action is appropriate. Despite the term 'nationalism', RN is not generally about foreign v. domestic exploitation of the resource 
since export and tax policies rarely distinguish between foreign and domestic companies engaged in production and trade.

Appropriation of that wealth, whether directly from state production or via taxation, is in accordance with the principles of resource nationalism only when public goods are produced. If a government, despite its rhetorical claims, is appropriating national wealth for private gain (e.g., corruption, patronage, status 'white elephant' projects to enhance its prestige and reputation, etc.) this cannot be considered 'resource nationalism'. By the same rationale, when important sectors of the society believe that they have not been getting their 'fair' share or one commensurate with their development needs and demand immediate, non-productive and unsustainable goods and services, neither is this 'resource nationalism'.

Governments in Latin America have often created private goods in the name of generating public goods and services. During the period when governments pursued import substitution industrialization (ISI, roughly 1930s-1970s) they legislated high tariffs on many manufactured products as a means of promoting national development. The tariffs generated benefits for the owners of the firms and their labor force, subsidized by the public purse and domestic consumers. But domestic consumers paid higher prices and the firms did not become internationally competitive and thus could not fuel greater industrialization and related employment opportunities. The labor unions in the protected industries (representing a minority of the labor sector) used their political influence to prolong protection of their firms. The provision of private goods during the ISI process was thus a major obstacle to a transition out of ISI and into a sustainable internationally competitive economy. ${ }^{15}$

Understanding when governments will adopt policies to turn national wealth into public goods requires thinking about three political factors: the institutional constraints within which governments operate, the inclusiveness of the political system regarding who is represented and the competitiveness of politics in the policymaking body.

Government institutions (constitutions, laws, offices and agencies) influence the content of legislation, the transparency of governmental behavior, the credibility of any

\footnotetext{
${ }^{15}$ On ISI see, Sebastian Edwards, Crisis and Reform in Latin America New York: Oxford University Press for the World Bank, 1995
} 
commitments entered into by the government and the incentives that lead people and firms to make the production, service and export market related decisions they do. ${ }^{16}$ Because countries vary in their institutions of government, the policies regulating commodity exports and taxation will also vary across countries. ${ }^{17}$

Government institutions also affect what resources constitute power and therefore which individuals and groups have influence. For example, before the new constitution in Bolivia gave indigenous communities veto over exploration in their geographic areas the only way they could stop exploration and production was through physically blocking access; since the communities are small and dispersed, it was difficult for them to resist the policy and the army. Today, and at times to the consternation of even indigenous President Evo Morales, small communities can lobby what they see as 'their' government. Institutions also affect for whom government will make policy (their own private interests, those of partisans, or for the public good) through the incentives they provide politicians. In addition, institutions affect how much discretion governments have in implementing laws and abiding by contracts.

Turning to the inclusiveness of the political system, I mean not only that a group is represented in the political system, but also that leaders are institutionally accountable to all the included groups. Accountability doesn't just happen at election time but requires that the behavior of elected officials be influenced by constraints that result from included groups making use of their rights as codified in the country's constitution. Newly included groups may demand a new constitution if they believe the current one has sufficient ambiguity and loopholes that politicians can effectively ignore demands from these new actors. ${ }^{18}$ Interest representation is a dynamic process and along the way, many actors will be tempted to create enclaves in which they can monopolize rents or even divert the process into new forms of elite rule. In short, one cannot have inclusiveness without transparency and credibility.

\footnotetext{
16 Brian Levy and Pablo T. Spiller, Regulations, Institutions, and Commitment: Comparative Studies of Telecommunications Cambridge: Cambridge University Press, 1996

17 J. Luis Guasch and Pablo Spiller, Managing the Regulatory Process: Design, Concepts, Issues, and the Latin America and Caribbean Story Washington, D.C.: The World Bank, 1999 pp. 27-29

18 Benjamin A. Olken, "Direct Democracy and Local Public Goods: Evidence from a Field Experiment in Indonesia" American Political Science Review Vol. 104, No. 2 May 2010
} 
Unfortunately, the poor have become a focus of government in many contemporary Latin American nations in a manner that continues the regional legacy of opaque and unaccountable institutions. This result is particularly detrimental (and paradoxical) because the poor have few resources with which to influence political elites and should therefore be most in favor of transparency and accountability.

The sudden shift from an exclusionary to an inclusionary political system does not necessarily shift public expenditure patterns from private to public goods. The previously excluded may not have confidence in the new political system and thus see this as an opportune moment to benefit NOW, thus demanding patronage rather than investment in the public goods that would contribute to sustainable development but generate benefits only in the medium to longer term. It shouldn't surprise us, then, that in Latin America the recently incorporated poor and indigenous groups want private goods in the name of justice and local development. After almost 200 years of their country's independence these groups have so little in terms of employment, education, health, and wealth, that it is hard for them to see pursuit of their private interests as 'unjust' or problematic given that the elites and middle classes routinely act in their private interests. Particularly when these groups comprise the vast majority of citizens in a country that exports valuable commodities (e.g., in Ecuador, Bolivia, and Peru), it is difficult for leaders (even if they so desire) to argue that reforming public policy in a manner that is sustainable over the medium to long term is better than simply redistributing today's wealth.

The impact of government institutions and the inclusiveness of the political system needs to be considered alongside the process of governing - that is, the level of political competition in policymaking. Political competition within the deliberative body that designs policy (e.g., the legislature in a democracy) is the key to getting politicians to view the delivery of public goods as in their career interests. ${ }^{19}$ Competitive deliberative bodies are more likely to develop independent legal systems to protect what is broadly known as 'property rights' - which include not only physical property, but contractual

\footnotetext{
${ }^{19}$ Ames, Barry Political Survival: Politicians and Public Policy in Latin America 1987; Geddes, Barbara. Politician's Dilemma: Building State Capacity in Latin America 1994; Pablo T. Spiller, Ernesto Stein and Mariano Tommas, "Political Institutions, Policymaking Processes, and Policy Outcome: An Intertemporal Transactions Framework" Washington, DC: InterAmerican Development Bank, April 2003
} 
obligations and civil rights - because everyone knows that at some point their groups will not be running the government and thus they want protection from those in office. Because revenues generated by exports can be opaque, competitive politics will be more likely to shed light on how much revenue comes in and how it is spent. Finally, when different political groups are evenly balanced within the body that deliberates and designs policy, they will have equal access to patronage. In this context, patronage offers no advantage, leading politicians to compete more on the basis of provision of public goods.

Understanding Latin American commodity exporters' inability to generate commodity wealth into sustainable and inclusive development requires thinking not just about economics and commodities, but about political institutions, political inclusiveness and political competition.

\section{CONCLUSION}

This analysis of the commodity boom and social welfare in Latin America suggests that though commodity export policies differ, their impacts on national development are less dependent on the state-market balance or political ideology than on what governments do with the income their policies generate. Because pro-market reforms failed to promote development during the 1980s-90s it is easy to think that additional wealth in the hands of a government that articulates a vision for national development will mean improvement for those at the bottom. But the experience of Venezuela and Argentina during the commodity boom demonstrates that state-oriented governments can use their wealth to support subgroups that become privileged supporters of the government, dependent upon the provision of private goods at the expense of public goods. National wealth may be wasted through state-directed development policies and less money may be invested wisely in social and economic development.

Politics oriented around the issue of sustainable development represent the fundamental issue for those concerned with poverty and equity. Provision of support to people at the bottom while undertaking structural reforms is a challenge for any government. In the context of corrupt governments and low public trust, this is an even greater challenge for most Latin American countries. 
TABLES AND FIGURES

Table 1: Main Commodity Exports, 2010-2012

\begin{tabular}{clclclcc}
\hline 2010-12 & First & Share & Second & Share & Third & Share & Sum \\
\hline ARG & Soybean meal & 26.5 & Soybeans & 12.6 & Soybean oil & 12.5 & 51.5 \\
BOL & Gas & 59.2 & Zinc & 13.4 & Soybean meal & 6.3 & 78.9 \\
BRA & Iron ore & 30.4 & Crude oil & 16.7 & Soybeans & 12.7 & 59.8 \\
CHL & Copper & 94.0 & Iron ore & 3.2 & Fishmeal & 1.1 & 98.3 \\
COL & Crude oil & 61.6 & Coal & 22.5 & Coffee & 7.5 & 91.6 \\
ECU & Crude oil & 71.3 & Banana & 13.8 & Shrimp & 7.0 & 92.2 \\
HND & Coffee & 44.6 & Banana & 15.6 & Palm oil & 11.3 & 71.5 \\
PER & Copper & 51.6 & Zinc & 8.7 & Fishmeal & 8.5 & 68.9 \\
PRY & Soybeans & 43.4 & Beef & 19.2 & Corn & 9.1 & 71.7 \\
TTO & Gas & 45.7 & Crude oil & 33.1 & Iron ore & 20.4 & 99.2 \\
URY & Beef & 36.9 & Soybeans & 24.5 & Rice & 12.2 & 73.6 \\
VEN & Crude oil & 96.5 & Iron ore & 2.1 & Aluminum & 0.9 & 99.6 \\
\hline
\end{tabular}

Notes: The table reports the average share of each country's three main commodity exports in their total exports of the 33 commodities considered here.

Source: Gross, After the Boom, p.34 
Table 2: Poverty Rates

Table 2

Poverty Rates 2000-2017

\begin{tabular}{|l|r|r|r|r|r|r|r|r|r|r|r|r|r|r|r|r|r|r|}
\hline Country & $\mathbf{2 0 0 0}$ & $\mathbf{2 0 0 1}$ & $\underline{\mathbf{2 0 0 2}}$ & $\mathbf{2 0 0 3}$ & $\mathbf{2 0 0 4}$ & $\mathbf{2 0 0 5}$ & $\mathbf{2 0 0 6}$ & $\mathbf{2 0 0 7}$ & $\mathbf{2 0 0 8}$ & $\mathbf{2 0 0 9}$ & $\mathbf{2 0 1 0}$ & $\mathbf{2 0 1 1}$ & $\mathbf{2 0 1 2}$ & $\mathbf{2 0 1 3}$ & $\mathbf{2 0 1 4}$ & $\mathbf{2 0 1 5}$ & $\mathbf{2 0 1 6}$ & $\mathbf{2 0 1 7}$ \\
\hline Argentina & 5,7 & 9,42 & 13,99 & 7,05 & 5,37 & 3,89 & 3,33 & 2,94 & 2,56 & 2,59 & 1,11 & 0,95 & 0,8 & 0,75 & 0,74 & NA & 0,58 & 0,44 \\
\hline Bolivia & 28,65 & 22,84 & 24,74 & NA & 13,68 & 19,32 & 16,38 & 12,44 & 11,05 & 10,46 & NA & 7,29 & 8,2 & 6,86 & 5,8 & 6,35 & 7,07 & 5,8 \\
\hline Brazil & NA & 11,59 & 10,31 & 11,09 & 9,73 & 8,64 & 7,2 & 6,81 & 5,59 & 5,41 & NA & 4,72 & 3,77 & 3,82 & 2,76 & 3,37 & 4,27 & 4,83 \\
\hline Chile & 4,38 & NA & NA & 4,16 & NA & NA & 2,35 & NA & NA & 2,59 & NA & 1,56 & NA & 0,92 & NA & 1,3 & NA & 0,75 \\
\hline Colombia & 16,37 & 19,67 & 14,3 & 11,95 & 10,88 & 9,71 & NA & NA & 10,35 & 8,87 & 7,72 & 6,26 & 6,2 & 5,68 & 5,03 & 4,54 & 4,53 & 3,92 \\
\hline Ecuador & 28,15 & NA & NA & 14,46 & 15 & 12,14 & 8,08 & 8,45 & 7,46 & 7,18 & 5,62 & 4,67 & 4,46 & 3,24 & 2,63 & 3,44 & 3,58 & 3,21 \\
\hline Mexico & 2,9 & NA & 2,09 & NA & 2 & 2,18 & 1,25 & NA & 1,75 & NA & 1,59 & NA & 1,2 & NA & 1,12 & NA & 0,66 & NA \\
\hline Peru & 16,77 & 17,28 & 15,01 & 11,75 & 13,46 & 15,34 & 13,34 & 11,01 & 8,96 & 6,99 & 5,46 & 5,19 & 4,73 & 4,31 & 3,68 & 3,55 & 3,47 & 3,37 \\
\hline Venezuela & NA & 10,96 & 18,23 & 22,7 & 19,76 & 18,86 & 10,22 & NA & NA & NA & NA & NA & NA & NA & NA & NA & NA & NA \\
\hline
\end{tabular}

Percent population living in households with income per person below the poverty line $\mathrm{NA}=$ not available

Source: Povcal Net: online tool for poverty measurement developed by the Development Research Group of The World Bank http://iresearch.worldbank.org/PovcalNet/home.aspx 
Table 3: Gini Index (see attached Excel spreadsheet)

Gini Index

\begin{tabular}{|l|r|r|r|r|r|r|r|r|r|r|r|r|r|r|r|r|r|r|r|l|}
\hline Country & $\underline{2000}$ & $\underline{2001}$ & $\underline{2002}$ & $\underline{2003}$ & $\underline{2004}$ & $\underline{2005}$ & $\underline{2006}$ & $\underline{2007}$ & $\underline{2008}$ & $\underline{2009}$ & $\underline{2010}$ & $\underline{2011}$ & $\underline{2012}$ & $\underline{2013}$ & $\underline{2014}$ & $\underline{2015}$ & $\underline{2016}$ & $\underline{2017}$ & & $\underline{\text { Summary 2015-2017 }}$ \\
\hline Argentina & 51,1 & 53,3 & 53,8 & 50,7 & 48,3 & 47,7 & 46,6 & 46,3 & 44,5 & 43,9 & 43 & 42,3 & 41,1 & 41 & 41,4 & & & & & no data \\
\hline Bolivia & 61,64 & 57,4 & 59,31 & & 55,01 & 58,53 & 56,67 & 54,53 & 50,82 & 49,22 & & 46,08 & 46,58 & 47,59 & 47,83 & 46,73 & 44,64 & 44,02 & & improv \\
\hline Brazil & & 58,41 & 58,11 & 57,56 & 56,48 & 56,32 & 55,65 & 54,93 & 54,04 & 53,69 & & 52,95 & 52,69 & 52,77 & 51,47 & 51,32 & 53,67 & 53,32 & & worsen \\
\hline Chile & 52,77 & & & 51,49 & & & 48,22 & & & 48,97 & & 47,62 & & 47,26 & & 47,65 & & 46,59 & & improv \\
\hline Colombia & 58,68 & 57,2 & 55,79 & 53,37 & 54,84 & 53,71 & & & 55,54 & 54,39 & 54,73 & 53,52 & 52,75 & 52,82 & 52,73 & 51,1 & 50,84 & 49,72 & & improv \\
\hline Ecuador & 56,38 & & & 53,36 & 53,93 & 53,09 & 52,19 & 53,3 & 49,73 & 48,45 & 48,73 & 45,88 & 46,11 & 46,86 & 44,99 & 45,95 & 45,02 & 44,67 & & improv \\
\hline Mexico & 52,58 & & 50,09 & & 50,03 & 50,12 & 48,94 & & 49,88 & & 47,21 & & 48,71 & & 48,72 & & 48,31 & & & stagnate \\
\hline Peru & 49,08 & 51,32 & 53,59 & 53,0 & 49,88 & 50,45 & 50,33 & 50,03 & 47,47 & 47,02 & 45,54 & 44,66 & 44,45 & 43,89 & 43,15 & 43,36 & 43,65 & 43,3 & & stagnate \\
\hline Venezuela & & 48,22 & 50,56 & 50,37 & 49,82 & 52,37 & 46,94 & & & & & & & & & & & & & worsen \\
\hline
\end{tabular}

Source: Povcal Net: the online tool for poverty measurement developed by the Development Research Group of The World Bank, http://iresearch.worldbank.org/PovcalNet/home.aspx

\section{REFERENCES}

Ames, B. (1987). Political Survival: Politicians and Public Policy in Latin America. Chicago: University of Chicago Press.

Avendano, R.; Melguizo, A.; Miner, S. (2017). Chinese FDI in Latin America: New Trends with Global Implications. Washington DC: Atlantic Council.

Economic Commission for Latin America and the Caribbean (ECLAC). (2017). Foreign Direct Investment, ECLAC keynotes for development. ISSN 2522-7459 N 1.

. (2018). Foreign Direct Investment in Latin America and the Caribbean (LC/PUB.2018/13-P), Santiago.

Edwards, S. (1995). Crisis and Reform in Latin America. New York: Oxford University Press for the World Bank.

Gallagher, K. P.; Myers, M. (2019). "China-Latin America Finance Database," Washington: Inter-American Dialogue.

Geddes, B. (1994). Politician's Dilemma: Building State Capacity in Latin America. Berkeley: University of California Press.

Gruss, B. (2014). "After the Boom - Commodity Prices and Economic Growth in Latin America and the Caribbean", Working Paper, 14/154 International Monetary Fund.

Guasch, J. L.; Spiller, P. T. (1999). Managing the Regulatory Process: Design, Concepts, Issues, and the Latin America and Caribbean Story. Washington, D.C.: The World Bank.

Levy, B.; Spiller, P. T. (1996). Regulations, Institutions, and Commitment: Comparative Studies of Telecommunications. Cambridge: Cambridge University Press.

Olken, B. A. (2010). "Direct Democracy and Local Public Goods: Evidence from a Field Experiment in Indonesia", American Political Science Review, 104(2), pp. 243-267 
Public Radio International. (2012). Argentina likely manipulating Big Mac prices to keep inflation seemingly lower, February 7.

Spiller, P. T.; Stein, E.; Tommas, M. (2003). Political Institutions, Policymaking Processes, and Policy Outcome: An Intertemporal Transactions Framework, Washington, DC: InterAmerican Development Bank.

Taylor, M. M. (2016). "Latin America's Savings Problem" Council on Foreign Relations July 14 https://www.cfr.org/blog/latin-americas-savings-problem

The Economist. (2017). Argentina's new, honest inflation statistics, May 25.

The World Bank. (2016). The Commodity Cycle in Latin America: Mirages and Dilemmas. SEMIANNUAL REPORT Office of the Regional Chief Economist.

United Nations Development Programme, Human Development Report, $<$ http://hdr.undp.org/en/humandev>. 